\title{
POTENSI PEMANFAATAN ATAP GEDUNG UNTUK PLTS DI KANTOR DINAS PEKERJAAN UMUM, PERUMAHAN DAN ENERGI SUMBER DAYA MINERAL (PUP-ESDM) PROVINSI DAERAH ISTIMEWA YOGYAKARTA
}

\author{
Defi Rizkasari $^{1)}$, Wahyu Wilopo ${ }^{2)}$, Mohammad Kholid Ridwan ${ }^{3)}$ \\ 1,2,3 Magister Teknik Sistem UGM, \\ JL. Teknika Utara, No.3, Barek, Kocoran, Caturtunggal, Kec. Depok, Kabupaten Sleman, \\ Daerah Istimewa Yogyakarta 55281
}

Email :defi.rizkasari@mail.ugm.ac.id ${ }^{1)}$,wilopo_w@ugm.ac.id ${ }^{2}$, kholid@ugm.ac.id ${ }^{3)}$

\begin{abstract}
ABSTRAK
Konsumsi energi listrik di Indonesia dari tahun ke tahun mengalami peningkatan. Penjualan energi listrik PLN tahun 2018 sebesar 234.617,88 GWh meliputi sektor industri, sektor rumah tangga, sektor komersial, dan sektor publik. Sedangkan konsumsi energi listrik di D. I. Yogyakarta tahun 2018 sebesar 2.857,06 GWh meliputi sektor rumah tangga, sektor industri, sektor bisnis, sektor sosial, sektor gedung kantor pemerintahan dan penerangan jalan umum. Dalam memenuhi permintaan energi listrik, pembangkit listrik yang terpasang di Yogyakarta terdiri dari PLTMH, PLTBm, PLTS dan PLTHybrid dengan kapasitas terpasang sebesar 4,84 MW sehingga kelistrikan di Yogyakarta dipasok dari jaringan interkoneksi Jawa-Madura-Bali. Sumber daya energi yang digunakan oleh jaringan interkoneksi umumnya menggunakan energi fosil (batubara). Oleh karena itu kita memerlukan pengganti bahan bakar fosil di masa depan. Pemanfaatan energi terbarukan salah satunya pengoptimalan energi surya yang dapat diterapkan pada daerah perkotaan. Sektor bangunan mengkonsumsi hingga $40 \%$ dari total energi tahunan. Salah satu gedung yang dapat menerapkan pemanfaatan energi terbarukan yaitu gedung kantor Dinas PUP-ESDM D. I. Yogyakarta. Penelitian ini bertujuan untuk mengetahui potensi daya yang dihasilkan dari PLTS atap jika dibangun pada gedung Dinas Pekerjaan Umum, Perumahan dan Energi Sumber Daya Mineral (PUP-ESDM) D. I. Yogyakarta. Penelitian dilakukan dengan melakukan simulasi energi menggunakan software HelioScope. Hasil simulasi menunjukkan sisi timur gedung 1, sisi timur gedung 2, sisi timur gedung 3, sisi barat gedung 2 dan sisi utara gedung 2 merupakan lokasi optimal fotovoltaik. Total potensi energi yang dihasilkan dari kelima atap tersebut sebesar 73.484,5 kWh/tahun dan mampu menyuplai kebutuhan energi Dinas PUP-ESDM sebesar 74,42\%.
\end{abstract}

Kata Kunci : Energi Terbarukan, Fotovoltaik, HelioScope, Produksi Energi.

\section{ABSTRACT}

Electricity consumption in Indonesia from year to year has increased. The sales of PLN 2018 electricity in 234,617.88 GWh covering industrial sector, household sector, commercial sector, and public sector. While electrical energy consumption in D. I. Yogyakarta in 2018 of 2,857.06 GWh covering household sector, industrial sector, business sector, social sector, government office building sector and public street lighting. In fulfilling the demand of electrical energy, Yogyakarta installed power plant consists of PLTMH, PLTBm, PLTS and PLTHybrid with an installed capacity of $4.84 \mathrm{MW}$ so that electricity in Yogyakarta is supplied from the interconnection network of Java-Madura-Bali. Energy resources used by interconnection networks generally use fossil energy (coal). Therefore we need a substitute for future fossil fuels. Utilization of renewable energy is one of the solar energy optimizations that can be applied to urban areas. The building sector consumes up to $40 \%$ of total annual energy. One of the buildings that can apply the utilization of renewable energy is the office building PUP-ESDM D. I. Yogyakarta. This research aims to know the potential power generated from the PLTS roofing if it is built on the office building Public Works, housing and Energy Mineral resources (PUP-ESDM) D. I. Yogyakarta. Research is conducted by conducting energy simulations using the HelioScope software. Simulated results show the east side of Building 1, the east side of Building 2, the east side of Building 3, the west side of Building 2 and the north side of Building 2 is the optimal location of photovoltaics. The Total energy potential generated from these five roofs is 73,484.5 kWh/year and is able to supply the energy needs of the PUP-ESDM office by $74.42 \%$. 
Keywords: renewable energy, photovoltaic, HelioScope, energy production.

\section{Pendahuluan}

Konsumsi energi listrik dari tahun ke tahun mengalami peningkatan. Penjualan tenaga listrik PLN tahun 2018 sebesar 234.617,88 GWh meliputi sektor industri, sektor rumah tangga, sektor komersial, dan sektor publik (Statistik Ketenagalistrikan, 2019). Sedangkan konsumsi energi listrik di D. I. Yogyakarta tahun 2018 sebesar 2.857,06 GWh meliputi sektor rumah tangga, sektor industri, sektor bisnis, sektor sosial, sektor gedung kantor pemerintahan dan penerangan jalan umum (Statistik PLN, 2019). Dalam memenuhi permintaan energi listrik, pembangkit listrik yang terpasang di D. I. Yogyakarta terdiri dari PLTMH dengan kapasitas 1 MW, PLTBm 3,80 MW, PLTS 0,02 MW dan PLTHybrid 0,02 MW sehingga untuk memenuhi permintaan energi listrik masyarakat belum tercukupi (Statistik Ketenagalistrikan, 2018). Hal ini dikarenakan daerah D. I. Yogyakarta tidak memiliki potensi energi primer sehingga permintaan energi primer seperti batubara, minyak bumi dan gas dipasok dari daerah lain.

Energi listrik di D. I. Yogyakarta dipasok melalui jaringan interkoneksi Jawa-Madura-Bali karena belum adanya pembangkit listrik yang dapat memenuhi permintaan listrik masyarakat D. I. Yogyakarta. Sumber daya energi yang digunakan oleh jaringan interkoneksi umumnya menggunakan sumber daya batubara (Badruzzaman, 2013). Oleh karena itu manusia memerlukan suatu energi pengganti bahan bakar fosil dimasa depan. Penggunaan energi terbarukan di Indonesia meliputi PLTMH 0,41\%, PLTBM 2,71\%, PLTS 0,09\% dan PLTHybrid 0,01\% (Statistik Ketenagalistrikan, 2018). Pemanfaatan energi terbarukan salah satunya pengoptimalan energi surya yang dapat diterapkan pada daerah perkotaan. Sektor bangunan mengkonsumsi hingga $40 \%$ dari total energi tahunan (UNEP, 2009). Energi surya merupakan energi yang potensial dikembangkan di Indonesia mengingat Indonesia terletak di daerah khatulistiwa. Energi surya yang dapat dibangkitkan untuk seluruh daratan Indonesia yang mempunyai luas 2 juta $\mathrm{km}^{2}$ adalah $4,8 \mathrm{kWh} / \mathrm{m}^{2} / \mathrm{hari}$ atau setara dengan $112.000 \mathrm{GWp}$ yang didistribusikan (Hasan, 2012).

D. I. Yogyakarta merupakan salah satu daerah perkotaan yang padat penduduk dan memiliki bangunan yang padat sehingga pemanfaatan atap bangunan dapat digunakan sebagai PLTS untuk sumber daya energi. Salah satu gedung yang dapat menerapkan pemanfaatan energi terbarukan yaitu gedung kantor Dinas PUP-ESDM D. I. Yogyakarta. Pada gedung tersebut telah dibangun fotovoltaik, namun pemasangan fotovoltaik belum optimal dikarenakan luasan pemasangan fotovoltaik kecil sementara potensi lokasi yang akan dipasang sangat luas. Penelitian ini bertujuan untuk mengetahui potensi daya optimal yang dihasilkan dari PLTS atap jika dibangun pada gedung Dinas Pekerjaan Umum, Perumahan dan Energi Sumber Daya Mineral (PUP-ESDM) D. I. Yogyakarta.

Penelitian terdahulu membahas tentang analisis potensi atap bangunan kampus sebagai lokasi penempatan panel surya sebagai sumber listrik (Tarigan dan Kartikasari, 2017). Penelitian ini dilakukan untuk mengetahui potensi pemanfaatan area atap bangunan kampus Universitas Surabaya untuk pemasangan sistem Pembangkit Listrik Tenaga Surya (PLTS). Penelitian ini menggunakan perangkat lunak SolarGIS-PVplanner untuk melakukan simulasi. Simulasi sistem PLTS ini gridconnected dengan menggunakan jenis panel surya monocrystalline produksi Sunpower Model SPR320NE-WHT-D dengan kapasitas $320 \mathrm{Wp}$ per panel. Pada penelitian ini didapatkan hasil yaitu area atap bangunan seluas $10.353 \mathrm{~m}^{2}$ dan kapasitas energi listrik yang dapat dibangkitkan sebesar 2.030 $\mathrm{kWp}$.

\section{Tinjauan Pustaka}

\subsection{Pembangkit Listrik Tenaga Surya (PLTS)}

Sebuah teknologi pembangkit listrik yang mengkonversi energi foton dari surya menjadi energi listrik disebut Pembangkit Listrik Tenaga Surya (PLTS). Sel - sel fotovoltaik pada panel surya melakukan konversi dari energi foton menjadi energi listrik. Sel fotovoltaik merupakan lapisan tipis dari silikon ( $\mathrm{Si}$ ) murni atau bahan semikonduktor, sehingga apabila bahan tersebut mendapat energi 
foton akan mengeksitasi elektron dari ikatan atomnya menjadi elektron yang bergerak bebas, dan pada akhirnya akan mengeluarkan tegangan listrik arus searah (Buresh,1983).

Prinsip sel surya (fotovoltaik) yaitu apabila dioda semikonduktor bekerja dalam proses tak seimbang dan berdasarkan efek fotovoltaik. Pada saat itu sel surya menghasilkan tegangan 0,5 - 1 Volt tergantung dari intensitas cahaya matahari dan jenis zat semikonduktor yang dipakai. Untuk intensitas energi yang ada dalam sinar matahari yang sampai ke permukaan bumi besarnya sekitar 1000 Watt. Tapi karena daya guna konversi energi radiasi menjadi energi listrik berdasarkan efek fotovoltaik baru mencapai $25 \%$, sehingga produksi listrik maksimal yang dihasilkan sel surya baru mencapai 250 watt per $\mathrm{m}^{2}$ (Salman, 2013).

\subsection{Sistem PLTS}

Berdasarkan teknologi yang digunakan PLTS dibagi menjadi dua sistem yaitu sistem PLTS grid-connected dan PLTS Off-Grid (Stand Alone). PLTS grid-connected atau PLTS terinterkoneksi adalah sistem PLTS yang terhubung dengan jaringan PLN. Manfaat dari PLTS grid-connected dapat menghasilkan listrik yang bebas emisi dan ramah lingkungan. Sistem ini memberikan nilai tambah pada konsumen karena dapat mengurangi tagihan listrik rumah tangga atau perkantoran (Putra, 2015).

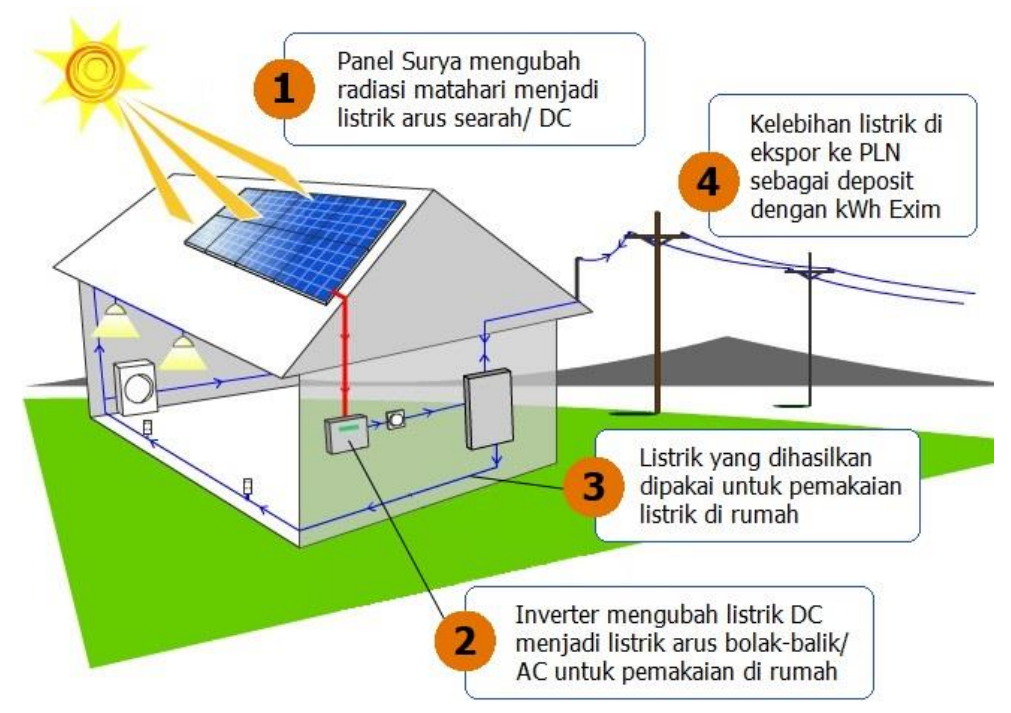

Gambar 1. Sistem PLTS Grid Connected (www.kewsolar.co.uk/techinfo/panels.aspx, 2020).

PLTS Off - Grid (Stand Alone) adalah jenis sistem PLTS yang dirancang untuk menghasilkan energi listrik secara mandiri dalam memenuhi kebutuhan beban listrik. PLTS Off - Grid biasanya terdapat pada daerah pedalaman atau pulau-pulau besar yang tidak mendapatkan pasokan listrik. 


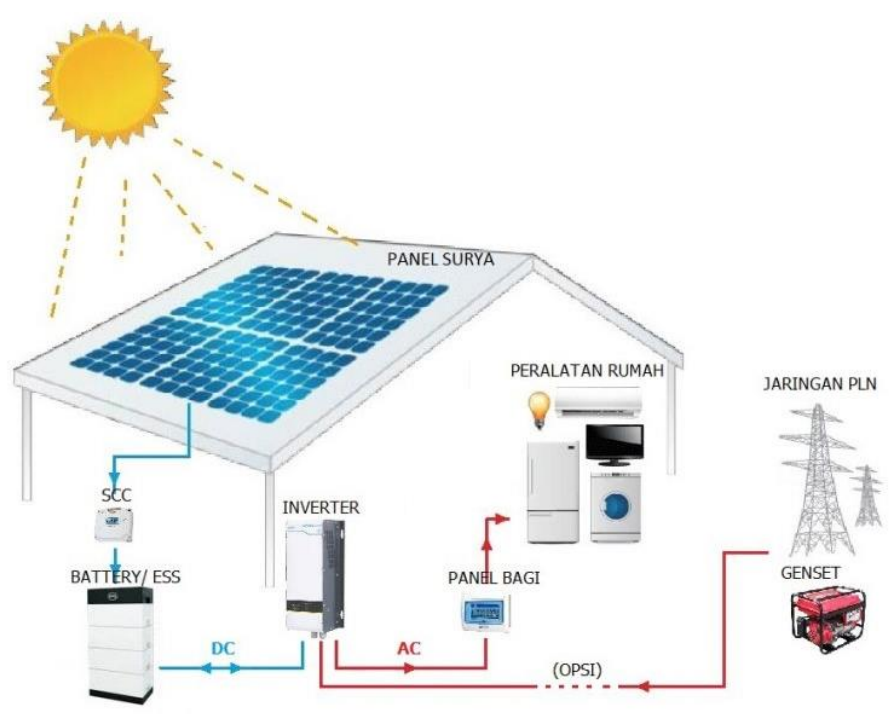

Gambar 2. Sistem PLTS Off-Grid (www.sunergi.co.id/id/sistem-off-grid, 2020).

\subsection{HelioScope}

HelioScope adalah sebuah program baru yang bersifat open software berbasis website. HelioScope diperkenalkan oleh Folsom Lab USA yang digunakan untuk merancang sistem fotovoltaik seperti beberapa fitur PVSyst dan menambahkan fungsionalitas desain AutoCAD, yang memungkinkan perancang untuk melakukan desain lengkap dalam satu paket. Alamat lokasi, konfigurasi array, modul PV dan spesifikasi inverter adalah syarat input utama yang diperlukan HelioScope. Perangkat lunak ini memungkinkan pengguna untuk memperkirakan produksi energi yang menghitung atas kerugian akibat cuaca dan iklim. Shading, pengkabelan, efisiensi komponen, ketidakcocokan panel, dan penggunaan lama (penuaan) bisa juga dianalisis untuk memberikan rekomendasi untuk peralatan dan tata letak susunan. Alat ini menampilkan produksi tahunan, kumpulan data cuaca, rasio kinerja, dan parameter sistem lainnya untuk hasil simulasi (Umar et al, 2018).

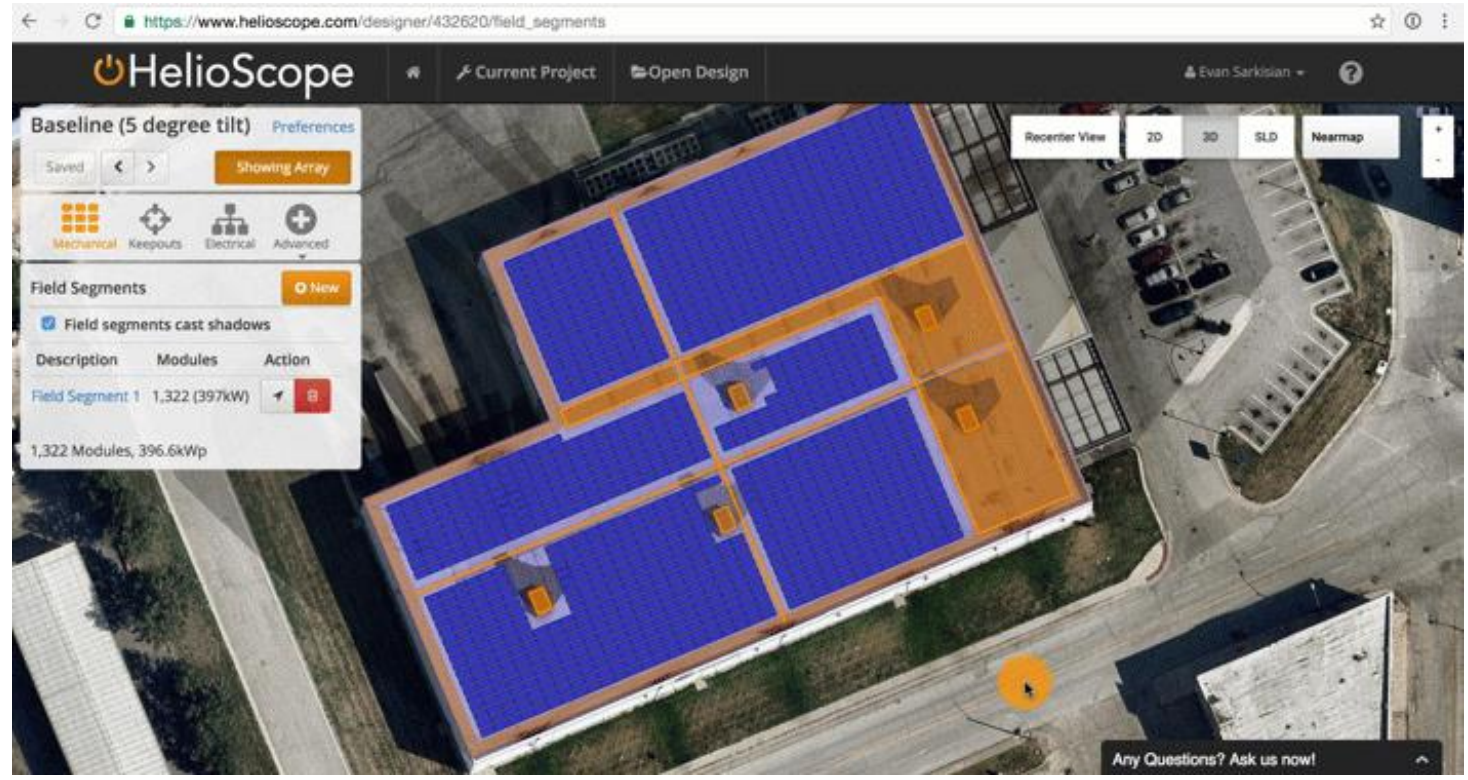

Gambar 3. Tampilan HelioScope (www.helioscope.com, 2020).

Pada penelitian ini menggunakan HelioScope dimana perancang dapat memasukkan lokasi gedung yang akan diteliti dan langsung terkoneksi dengan Google Earth sehingga dapat mempermudah perancang dalam merancang sistem PLTS pada gedung yang akan diterapkan. Pada 
HelioScope juga telah disediakan database panel surya dan inverter sehingga perancang dapat memilih komponen PLTS. Selain HelioScope ada beberapa aplikasi untuk merancang PLTS seperti PVSyst, System Advisor Model (SAM), dan Homer.

\section{Metodologi Penelitian} berikut :

Penelitian dilakukan di Dinas PUP-ESDM D. I. Yogyakarta. Tahapan penelitian adalah sebagai

1. Melakukan observasi pada gedung Dinas PUP-ESDM D. I. Yogyakarta untuk mengetahui kondisi gedung, letak secara geografis serta mengumpulkan data-data yang menunjang penelitian.

2. Menghitung luasan atap untuk penempatan fotovoltaik menggunakan HelioScope, dimana pada HelioScope telah terhubung langsung dengan Google Earth.

3. Menentukan banyaknya modul surya yang dapat dipasang pada atap gedung dan daya yang diperoleh.

4. Melakukan simulasi dengan menggunakan HelioScope untuk menentukan produksi energi dari PLTS.

5. Mengetahui hasil produksi energi yang diperoleh.

\section{Hasil dan Pembahasan}

Kantor Dinas Pekerjaan Umum, Perumahan dan Energi Sumber Daya Mineral (PUP-ESDM) Yogyakarta merupakan gedung instansi pemerintah. Kantor Dinas PUP-ESDM Yogyakarta terletak di Jalan Bumijo No. 5 Bumijo, Kecamatan Jetis, Kota Yogyakarta. Kantor ini terletak pada latitude $7^{\circ} 47^{\prime} 11.64 " S$ dan longitude $110^{\circ} 21^{\prime} 44.89^{\prime \prime}$. Kantor Dinas PUP-ESDM DIY memiliki tiga gedung utama. Gedung Kantor Dinas PUP-ESDM DIY memiliki 2 lantai dengan luas area sebesar 3.703,72 $\mathrm{m}^{2}$. Kapasitas jaringan (PLN) yang terpasang pada tahun 2018 sebesar $71.500 \mathrm{Va}$ atau setara dengan 57.200 W. Konsumsi energi listrik pada tahun 2018 sebesar 98.773 kWh. Gedung kantor Dinas PUPESDM DIY ditunjukkan oleh Gambar 4.

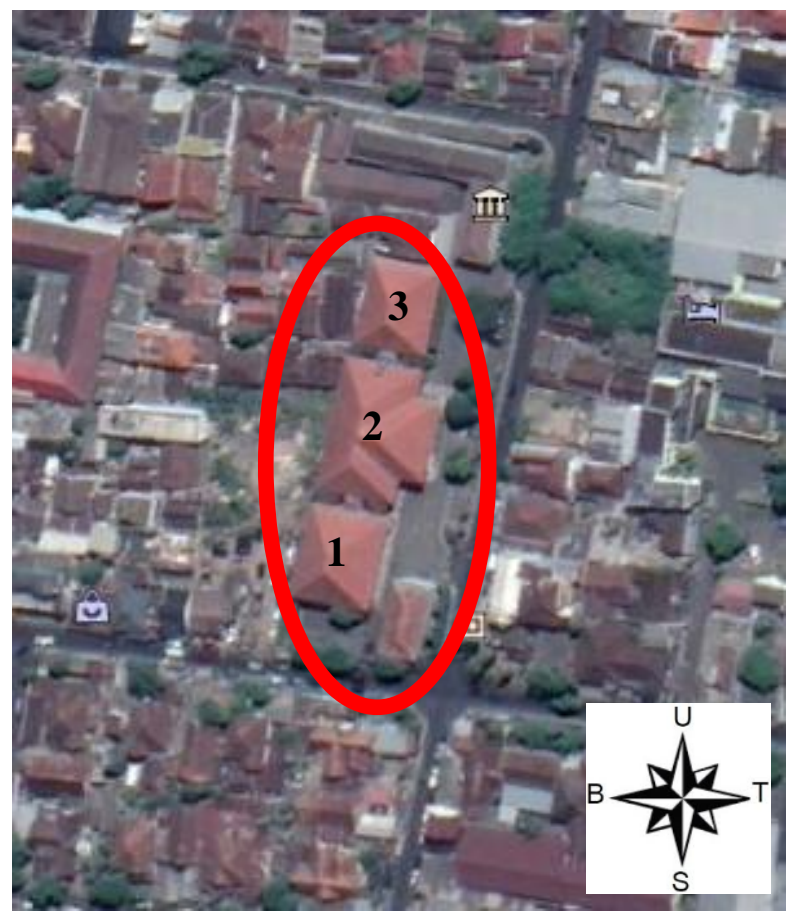

Gambar 4. Lokasi gedung kantor Dinas PUP-ESDM D. I. Y (Google Earth, 2020).

Untuk mengetahui potensi daya listrik optimal yang mampu dihasilkan dari atap gedung Dinas PUP-ESDM DIY maka yang perlu dilakukan yaitu mengetahui luas atap masing-masing gedung dari 
sisi atap gedung yaitu sisi utara, sisi timur, sisi selatan dan sisi barat. Namun yang akan dihitung hanya dari sisi utara, sisi timur dan sisi barat yang menerima pancaran sinar matahari dari terbit sampai terbenam karena posisi gedung berada pada bagian selatan garis khatulistiwa. Luasan atap dapat dilihat pada Tabel 1.

Tabel 1. Luas atap gedung Dinas PUP-ESDM DIY sisi utara, timur, dan barat

\begin{tabular}{cccc}
\hline \multirow{2}{*}{ Gedung } & \multicolumn{3}{c}{ Luasan Atap tiap sisi $\left(\mathrm{m}^{2}\right)$} \\
\cline { 2 - 4 } & Utara & Timur & Barat \\
\hline Gedung 1 & 30 & 42 & 42 \\
Gedung 2 & 30 & 33 & 81 \\
Gedung 3 & 30 & 42 & 42 \\
\hline
\end{tabular}

Pada tabel 1, dapat dilihat bahwa sisi terluas adalah sisi bagian timur dan barat dari masing-masing gedung sedangkan sisi terkecil adalah sisi bagian utara.

Setelah mengetahui luasan atap gedung, maka simulasi produksi energi listrik dengan menggunakan HelioScope dapat dilakukan. Pada simulasi ini, diperlukan input dari dua komponen fotovoltaik, yaitu modul surya dan inverter. Hal yang diperlukan dalam pemilihan modul surya yaitu ketersediaan modul surya pada database HelioScope. Modul surya yang dipilih dalam simulasi ini yaitu Jinko Solar, JKM 300P-72 (300W) yang diproduksi oleh Jinko Solar. Pemilihan modul surya Jinko Solar karena memiliki kualitas yang mumpuni dan menggunakan teknologi terbaik di kelasnya. Spesifikasi modul surya dapat dilihat pada Tabel 2.

Tabel 2. Spesifikasi panel surya Jinko Solar, JKM 300P-72 (300W).

\begin{tabular}{lcc}
\hline \multicolumn{1}{c}{ Modul Type } & \multicolumn{2}{c}{ JKM 300P } \\
\cline { 2 - 3 } & STC & NOCT \\
\hline Maximum Power (Pmax) & $300 \mathrm{Wp}$ & $221 \mathrm{Wp}$ \\
Maximum Power Voltage (Vmp) & $36.6 \mathrm{~V}$ & $33.7 \mathrm{~V}$ \\
Maximum Power Current (Imp) & $8.20 \mathrm{~A}$ & $6.56 \mathrm{~A}$ \\
Open-circuit Voltage (Voc) & 45.3 & $42.3 \mathrm{~V}$ \\
Short-circuit Current (Isc) & $8.84 \mathrm{~V}$ & $7.16 \mathrm{~A}$ \\
Module Efficiency STC & \multicolumn{2}{c}{$15.46 \%$} \\
Nominal operating cell temperature (NOCT) & \multicolumn{2}{c}{$45 \pm 2^{\circ} \mathrm{C}$} \\
Irradiance & $1000 \mathrm{~W} / \mathrm{m} 2$ & $800 \mathrm{~W} / \mathrm{m} 2$ \\
\hline
\end{tabular}

Pemilihan inverter disesuaikan dengan kapasitas kerja inverter yang mendekati kapasitas terpasang PLTS (Tabel 4). Inverter yang digunakan yaitu inverter Sunny Tripower, dimana inverter ini memiliki produksi energi yang efisiensinya tinggi, fleksibilitas desain yang baik, dan kompatibilitas dengan banyak modul surya. Inverter Sunny Tripower yang digunakan pada simulasi ini adalah Sunny Tripower 6000TL, Sunny Tripower 7000TL, Sunny Tripower 8000TL, Sunny Tripower 10000TL, dan Sunny Tripower 12000TL dengan spesifikasi masing-masing inverter dapat dilihat pada Tabel 3. 
Tabel 3. Spesifikasi Inverter Sunny Tripower 6000TL, 7000TL, 8000TL, 10000TL dan 12000TL

\begin{tabular}{lccccc}
\hline & \multicolumn{5}{c}{ Spesifikasi } \\
\cline { 2 - 6 } Karakteristik & $\begin{array}{c}\text { Sunny } \\
\text { Tripower } \\
6000 \mathrm{TL}\end{array}$ & $\begin{array}{c}\text { Sunny } \\
\text { Tripower } \\
7000 \mathrm{TL}\end{array}$ & $\begin{array}{c}\text { Sunny } \\
\text { Tripower } \\
8000 \mathrm{TL}\end{array}$ & $\begin{array}{c}\text { Sunny } \\
\text { Tripower } \\
10000 \mathrm{TL}\end{array}$ & $\begin{array}{c}\text { Sunny } \\
\text { Tripower } \\
12000 \mathrm{TL}\end{array}$ \\
\hline Max. DC power & $9000 \mathrm{Wp}$ & $13500 \mathrm{Wp}$ & $13500 \mathrm{Wp}$ & $13500 \mathrm{Wp}$ & $18000 \mathrm{Wp}$ \\
Max. input voltage & $1000 \mathrm{~V}$ & $1000 \mathrm{~V}$ & $1000 \mathrm{~V}$ & $1000 \mathrm{~V}$ & $1000 \mathrm{~V}$ \\
$\begin{array}{l}\text { MPP voltage range } \\
\text { / rated input voltage }\end{array}$ & $\begin{array}{c}295 \mathrm{~V}-800 \\
\mathrm{~V} / 580 \mathrm{~V}\end{array}$ & $\begin{array}{c}290 \mathrm{~V}-800 \\
\mathrm{~V} / 580 \mathrm{~V}\end{array}$ & $\begin{array}{c}330 \mathrm{~V}-800 \\
\mathrm{~V} / 580 \mathrm{~V}\end{array}$ & $370 \mathrm{~V} / 580 \mathrm{~V}$ & $\mathrm{~V} / 580 \mathrm{~V}$ \\
$\begin{array}{l}\text { Min. input voltage / } \\
\text { initial input voltage }\end{array}$ & $150 \mathrm{~V} / 188 \mathrm{~V}$ & $150 \mathrm{~V} / 188 \mathrm{~V}$ & $150 \mathrm{~V} / 188 \mathrm{~V}$ & $150 \mathrm{~V} / 188 \mathrm{~V}$ & $150 \mathrm{~V} / 188 \mathrm{~V}$ \\
$\begin{array}{l}\text { Max. input current } \\
\text { per string input A / } \\
\text { input B }\end{array}$ & $11 \mathrm{~A} / 10 \mathrm{~A}$ & $15 \mathrm{~A} / 10 \mathrm{~A}$ & $15 \mathrm{~A} / 10 \mathrm{~A}$ & $18 \mathrm{~A} / 10 \mathrm{~A}$ & $18 \mathrm{~A} / 10 \mathrm{~A}$ \\
$\begin{array}{l}\text { Rated power (@ } \\
\text { 230 V, 50 Hz) }\end{array}$ & $6000 \mathrm{~W}$ & $7000 \mathrm{~W}$ & $8000 \mathrm{~W}$ & $10000 \mathrm{~W}$ & $12000 \mathrm{~W}$ \\
$\begin{array}{l}\text { Max. apparent AC } \\
\text { power }\end{array}$ & $6000 \mathrm{Va}$ & $7000 \mathrm{Va}$ & $8000 \mathrm{Va}$ & $10000 \mathrm{Va}$ & $12000 \mathrm{Va}$ \\
Max. efficiency & $98 \%$ & $98 \%$ & $98 \%$ & $98 \%$ & $98 \%$ \\
\hline
\end{tabular}

Jumlah modul fotovoltaik dapat diketahui setelah mengetahui luasan atap serta menentukan kapasitas modul surya (berdasarkan data dimensi modul surya). Penentuan jumlah modul yang dapat dipasang dilakukan dengan HelioScope, dimana pada HelioScope penentuan jumlah modul menyesuaikan dengan luasan dan bentuk atap atau kemiringan atap gedung seperti pada Gambar 5 dengan kemiringan atap $30^{\circ}$.
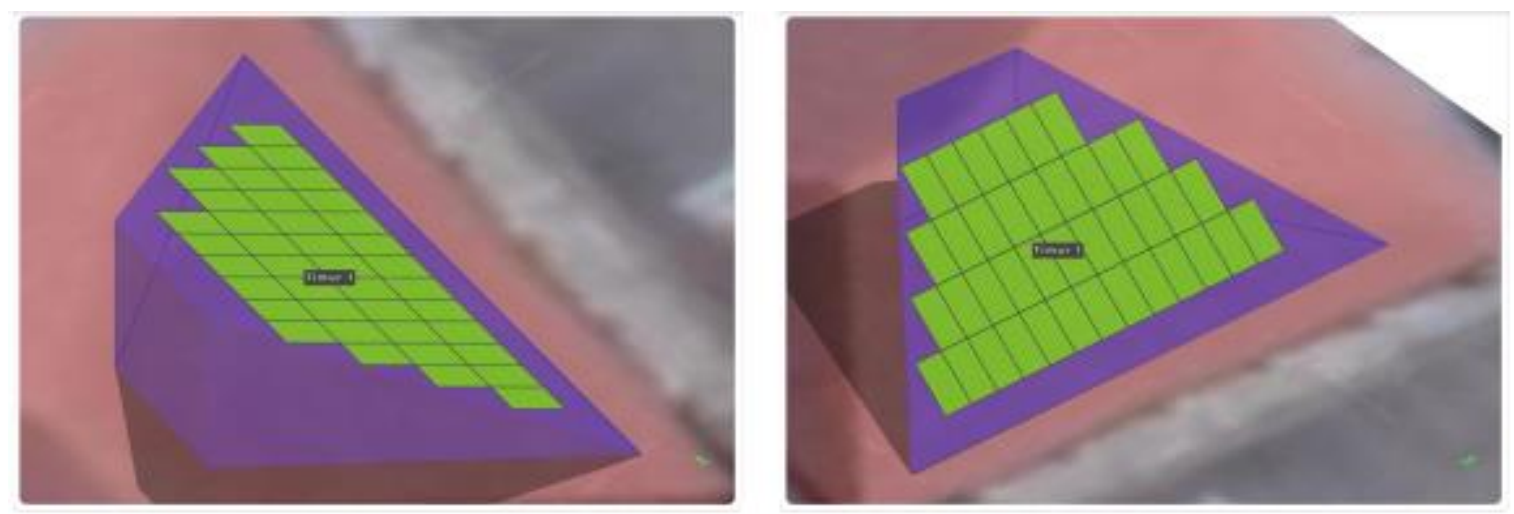

Gambar 5. Model 3D penempatan PLTS atap sisi Timur.

Setelah menentukan jumlah modul dengan menyesuaikan bentuk atap, maka dapat diketahui jumlah modul surya yang dapat dipasang pada atap gedung Dinas PUP-ESDM DIY dan jumlah inverter yang digunakan dapat dilihat pada Tabel 4. 
Tabel 4. Jumlah modul surya yang dapat dipasang pada atap gedung Dinas PUP-ESDM DIY dan penggunaan inverter.

\begin{tabular}{lccccr} 
Lokasi PLTS & $\begin{array}{c}\text { Jumlah } \\
\text { Inverter } \\
\text { (Unit) }\end{array}$ & $\begin{array}{c}\text { Kapasitas } \\
\text { Inverter (W) }\end{array}$ & $\begin{array}{c}\text { Jumlah } \\
\text { Modul (Unit) }\end{array}$ & $\begin{array}{c}\text { Kapasitas } \\
\text { Modul (Wp) }\end{array}$ & $\begin{array}{c}\text { Kapasitas } \\
\text { Terpasang } \\
\text { (Wp) }\end{array}$ \\
\hline Gedung 1 bag. Utara & 1 & 8000 & 25 & 300 & 7500 \\
Gedung 2 bag. Utara & 1 & 8000 & 26 & 300 & 7800 \\
Gedung 3 bag. Utara & 1 & 7000 & 23 & 300 & 6900 \\
Sub Total Bag. Utara & 3 & & 74 & & 22200 \\
Gedung 1 bag. Timur & 1 & 12000 & 40 & 300 & 12000 \\
Gedung 2 bag. Timur & 1 & 10000 & 32 & 300 & 9600 \\
Gedung 3 bag. Timur & 1 & 12000 & 39 & 300 & 11700 \\
Sub Total Bag. Timur & 3 & & 111 & & 33300 \\
Gedung 1 bag. Barat & 1 & 6000 & 20 & 300 & 6000 \\
Gedung 2 bag. Barat & 2 & 8000 & 53 & 300 & 15900 \\
Gedung 3 bag. Barat & 1 & 6000 & 20 & 300 & 5600 \\
Sub Total Bag. Barat & 4 & & 93 & & 27500 \\
\hline
\end{tabular}

Berdasarkan Tabel 4, dapat dilihat bahwa sisi timur dan sisi barat gedung dapat dipasangi modul surya paling banyak dengan jumlah modul pada sisi timur sebanyak 111 modul dan sisi barat sebanyak 93 modul. Kapasitas terpasang sisi timur sebesar $33.300 \mathrm{Wp}$ dan sisi barat sebesar 27.500 Wp. Sisi utara gedung merupakan jumlah paling sedikit untuk dipasangi modul yaitu 74 modul dengan kapasitas terpasang sebesar $22.200 \mathrm{Wp}$. Setelah mengetahui jumlah modul, inverter dan potensi daya terpasang, maka selanjutnya dapat mengetahui produksi energi yang dapat dihasilkan dari atap gedung dengan melakukan simulasi dengan menggunakan HelioScope. Potensi energi yang dihasilkan dari fotovoltaik yang dipasang pada gedung Dinas PUP-ESDM DIY dapat dilihat pada Tabel 5.

Tabel 5. Hasil simulasi produksi energi fotovoltaik Dinas PUP-ESDM DIY.

\begin{tabular}{crrrr}
\hline \multirow{2}{*}{ Gedung } & \multicolumn{2}{c}{ Produksi Energi Fotovoltaik (kWh/tahun) } & \multicolumn{1}{c}{ Total } \\
\cline { 2 - 3 } & \multicolumn{1}{c}{ Utara } & Timur & \multicolumn{1}{c}{ Barat } & (kWh/Tahun) \\
\hline Gedung 1 & $9.937,3$ & $15.427,6$ & $7.736,5$ & $33.101,4$ \\
Gedung 2 & $10.320,0$ & $12.246,6$ & $20.460,5$ & $43.027,1$ \\
Gedung 3 & $9.156,8$ & $15.029,8$ & $7.256,6$ & $31.443,2$ \\
Total & $\mathbf{2 9 . 4 1 4 , 1}$ & $\mathbf{4 2 . 7 0 4 , 0}$ & $\mathbf{3 5 . 4 5 3 , 6}$ & $\mathbf{1 0 7 . 5 7 1 , 7}$ \\
\hline
\end{tabular}

Berdasarkan tabel 4 dan tabel 5, lokasi penempatan fotovoltaik yang optimal yaitu pada atap sisi timur gedung 1 , sisi timur gedung 2 , sisi timur gedung 3 , sisi barat gedung 2 dan sisi utara gedung 2 dengan total kapasitas terpasang sebesar $57.000 \mathrm{Wp}$ dimana daya ini tidak melebihi kapasitas jaringan (PLN). Total potensi energi yang dihasilkan dari masing-masing atap yaitu sisi timur gedung 1 sebesar 15.427,6 kWh/tahun, sisi timur gedung 2 sebesar 12.246,6 kWh/tahun, sisi timur gedung 3 sebesar 15.029,8 kWh/tahun, sisi barat gedung 2 sebesar 20.460,5 kWh/tahun dan sisi utara gedung 2 sebesar 10.320,0 kWh/tahun. Total potensi energi yang dihasilkan dari kelima atap tersebut sebesar 73.484,5 kWh/tahun dan mampu menyuplai kebutuhan energi Dinas PUP-ESDM sebesar 74,42 \%.

\section{Kesimpulan}

Lokasi penempatan fotovoltaik yang optimal pada gedung Dinas PUP-ESDM yaitu pada atap sisi timur gedung 1 , sisi timur gedung 2 , sisi timur gedung 3 , sisi barat gedung 2 dan sisi utara gedung 2 dengan total potensi daya sebesar $57.000 \mathrm{Wp}$. Total produksi energi yang dihasilkan dari masingmasing atap yaitu sisi timur gedung 1 sebesar 15.427,6 kWh/tahun, sisi timur 2 sebesar 12.246,6 
$\mathrm{kWh} /$ tahun, sisi timur 3 sebesar 15.029,8 kWh/tahun, sisi barat gedung 2 sebesar 20.460,5 kWh/tahun dan sisi utara gedung 2 sebesar $10.320,0 \mathrm{kWh} /$ tahun. Total produksi energi yang dihasilkan dari kelima atap tersebut sebesar 73.484,5 kWh/tahun dan mampu menyuplai kebutuhan energi Dinas PUP-ESDM sebesar 74,42\%.

\section{Saran}

Dari penelitian ini diharapkan dapat menjadi masukan bagi peneliti yang lain mengenai PLTS. Saran dari penelitian ini adalah penelitian ini dapat ditambahkan dengan skema kebijakan energi yang berlaku di Indonesia sehingga dapat menarik minat masyarakat untuk penggunaan energi terbarukan khususnya energi surya.

\section{Daftar Pustaka}

Badruzzaman, Y. (2013). Roadmap Energy di Provinsi Daerah Istimewa Yogyakarta. Jurnal Teknik Elektro Terapan, 2(1), 18 - 30.

Buresh, M. (1983). Photovoltaic Energy System Design and Installation, McGraw Hill Book Company, United States of America.

Hasan, H. (2012). Perancangan Pembangkit Listrik Tenaga Surya Di Pulau Saugi. Jurnal Riset dan Teknologi Kelautan, 10(2). 169-180.

Putra, T. G. (2015). Analisa Unjuk Kerja Pembangkit Listrik Tenaga Surya 15 Kw Di Dusun Asah Teben Desa Datah Karangasem. Skripsi, Universitas Udayana.

Salman, R. (2013). Analisis Perencanaan Penggunaan Sistem Pembangkit Listrik Tenaga Surya (PLTS) Untuk Perumahan (Solar Home System). Majalah Ilmiah Bina Teknik, 1(1), 46-51.

Statistik Ketenagalistrikan 2018. (2019). Direktorat Jenderal Ketenagalistrikan Kementerian Energi dan Sumber Daya Mineral. Jakarta.

Statistik PLN 2018. (2019). Perusahaan Listrik Negara (PLN). Jakarta.

Tarigan, E., Kartikasari, F. D. (2017). Analisis Potensi Atap Bangunan Kampus sebagai Lokasi Penempatan Panel Surya Sebagai Sumber Energi Listrik. Jurnal Muara Sains, Teknologi, Kedokteran dan Ilmu Kesehatan, 1(1), 101-110.

Umar, N., Bora, B., Banerjee, C., Panwar, B. S. (2018). Comparison of Different PV Power Simulation Softwares: Case Study on Performance Analysis of 1 MW Grid-Connected PV Solar Power Plant. International Journal of Engineering Science Invention (IJESI), 7(7), 1124.

UNEP. (2009). Buildings And Climate Change: Summary For Decision-Makers. United Nations Environment Program.

www.earth.google.com/web/ Akses tanggal 10 Januari 2020.

www.helioscope.com/designer/ Akses tanggal 11 Juni 2020.

Www.kewsolar.co.uk/techinfo/panels.aspx Akses tanggal 11 Juni 2020.

www.sunergi.co.id/id/sistem-off-grid Akses tanggal 11 Juni 2020. 